\title{
Squeezing farmers in the poultry capital of the world
}

\author{
Review by Carrie Freshour* \\ Cornell University
}

\author{
Review of The Takeover: Chicken Farming and the Roots of \\ American Agribusiness, by Monica Gisolfi. (2017). Published by \\ University of Georgia Press. Available as hardcover, \\ paperback, and ebook; 128 pages. Publisher's website: \\ http://www.ugapress.org/index.php/books/takeover/
}

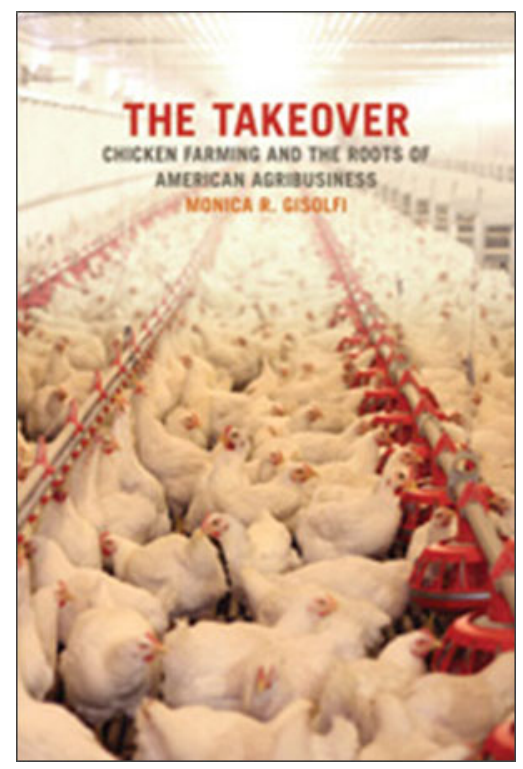

Submitted December 3, 2017 / Published online March 13, 2018

Citation: Freshour, C. (2018). Squeezing farmers in the poultry capital of the world [Book review]. Journal of Agriculture, Food Systems, and Community Development, 8(1), 187-189.

https://doi.org/10.5304/jafscd.2018.081.008

Copyright (C) 2018 by the Author. Published by the Lyson Center for Civic Agriculture and Food Systems. Open access under CC BY license.

$\mathrm{T}$ oday, Americans consume an average of 91 pounds (41 kilograms) of chicken annually, up from 28 pounds (13 kg) in 1960 (National Chicken Council, 2017). This growth was achieved through industry concentration and the transformation of farming. Between 1950 and 2007, the number of

Carrie Freshour is a $\mathrm{PhD}$ candidate in the department of Development Sociology at Cornell University. Her research interests include the political economy of food work, social reproduction, immigration, and racialization in the U.S. South. She is currently finishing her dissertation based on two years of ethnographic research in Northeast Georgia, where she worked for six months on the evisceration line in a large poultry processing plant. She also collected oral histories with current and former workers to document the daily struggles and experiences of Black and Latina women tied to the processing lines. She can be contacted at crf64@,cornell.edu. poultry farms decreased from 1.6 million to 27,000 , even as chicken production increased from 580 million to 9 billion birds raised per year (Pew Environment Group, 2011, p. 6). The average chicken farm now raises over 330,000 birds annually, as compared to 363 birds in 1950, with nearly all production under contract (Chrisman, 2016).

Monica Gisolfi's The Takeover: Chicken Farming and the Roots of American Agribusiness documents the poultry industry's "silent revolution" in upcountry Georgia. This revolution provided the model for contemporary forms of capital-intensive industrial agriculture. Popular narratives depict the rapid transformation of poultry production from small "yard flocks" to today's multibillion-dollar industry, as the result of the work of so-called 
"innovators" and "pioneers" like Jesse Jewell and John Tyson. Gisolfi paints a more critical picture, documenting the legacy of the cotton crop-lien system, discriminatory federal policies, and the industry's growth and consolidation through quasivertical integration. The result has been abundant profits for companies like Tyson, Purdue, and Pilgrim's Pride at the expense of contract growers and rural livelihoods. Industrial poultry's growth has exacerbated social inequalities and ecological degradation while simultaneously setting the blueprint for the expansion of industrial agriculture globally.

The Takeover covers nearly a century of poultry production. Gisolfi focuses on "white businessmen, USDA bureaucrats, and white farmers holding small plots"1 (p. 3). African Americans and women are relegated to the margins of this story, for which she credits "racist USDA policies that kept them from benefitting from the research, technology, and subsidies" (p. 3) essential to growth. Chapter one documents the cotton-topoultry shift. While the agricultural product changed, the structure of production endured, based on the "crop-lien" system where tenant farmers and sharecroppers were forced to grow ecologically destructive monocultures for northern markets on credit. These farmers became greatly indebted to landowners, a situation that worsened during the Great Depression as cotton prices plummeted. Gisolfi examines the effects of U.S. Department of Agriculture (USDA) interventions and New Deal policies, like the Agricultural Adjustment Act. Federal programs bolstered the expansion of white-owned large farms, incentivizing farmers to plow up their cotton fields. These payments increased inequality as landowners used the money to modernize their farms with machinery and electricity while displacing tenant farmers, sharecroppers, and small farmers. For many landowners, the chicken house soon replaced the tenant house.

Next, Gisolfi examines the World War II-era development of the poultry industry through

\footnotetext{
${ }^{1}$ Here, Gisolfi refers to farmers who owned a small acreage of land used for cotton production. Land ownership was crucial to transforming cotton production to poultry.
}

federal research, regulations, and subsidies. Other work examines this broader transformation (Gray, 2014; Striffler, 2005; Stuesse, 2016), but Gisolfi's regional focus contributes to a clearer understanding of the major integrators' actions. She documents the intimate relationships between wartime production and rural restructuring to local production decisions and industry partnerships. The War Food Order and the Steagall Amendment, among others, drastically transformed not only how the industry produces standardized "broiler" birds, but also who could afford to produce.

While New Deal policies and WWII production demands and regulations created the conditions for growth, white businessmen like Tyson and Jewell established the modern broiler industry through a system dependent on an impoverished South, wherein farmers had few alternatives. The "integrator business model" relied on (1) quasivertical integration, (2) the creation of a feed conversion contract, and (3) the forced sale of broiler housing and machinery to contract farmers. The integrators' profit margins grew alongside contract growers' debt. This unequal relationship became the norm whereby "growers' dependence soon became rooted in the ironic fact that they owned the means of production" (p. 37). After WWII, farmers with fewer than 10,000 birds were driven from the market. The number of poultry farms in upcountry Georgia fell, in some locations by 70 percent. Large farmers who could upgrade their chicken houses and technology to meet industry demands remained, but only by increasing debt. The policy and regulatory changes shifted the purpose of poultry farming from a rural livelihood meant to "save" the region to an activity meant to supplement "public" off-farm labor.

In the final chapter, Gisolfi addresses the poultry industry's degradation of the environment from 1939 to 1990. The drastic production increase resulted in an abundance of waste-literal chicken shit - that polluted regional rivers and sewer systems. Due to a close relationship with the USDA, the industry evaded any responsibility for mitigating the pollution. By briefly documenting the industry's devastating environmental effects, Gisolfi's book contributes to the subfield of 
political ecology, although here only tangentially. Another shortcoming of the book, which Gisolfi acknowledges, is the absence of an analysis of the effects of the policy changes on African American tenant farmers' and sharecroppers' livelihoods. Tenant farmers and sharecroppers constituted $95 \%$ of all Black farmers before WWII (p. 32). While their exclusion from industrial agriculture's commercialization is not Gisolfi's focus, white supremacy remains essential to the process of industrial growth. As evident in Pigford v. Glickman (1999), a textbook case of structural racism, attention to race-based exclusion and discrimination is critical to an analysis of growing inequality and rural restructuring at the heart of industrial agriculture (see Daniel, 2013). A fuller analysis of race in poultry farming would greatly complement influential studies on labor and race in animal processing (Gray, 2014; Ribas, 2015; Simon, 2017; Striffler, 2005; Stuesse, 2016).

Despite these criticisms, The Takeover compellingly critiques the growth of the U.S. poultry industry by examining increasing inequality from the perspective of USDA extension agents, white businessmen, and white farmers turned contract growers. Gisolfi provides an important social history of industrial agriculture with lessons for students of critical food studies, historians of the American South, and scholar-activists concerned with transforming our environmentally destructive and capitalist food system. In the epilogue, Gisolfi briefly comments on the global export of this model as the Jewells and Tysons of today "modernize" entire industries in Eastern Europe, Thailand, Brazil, and Mexico at a devastatingly rapid pace. "Modernization" comes at the expense of small farmers, consumers, and local ecologies. Gisolfi's work has broad implications for regions that have yet to "modernize" agricultural production along this profit-driven industrial model. Thus forewarned, there may be potential for farmers, consumers, low-wage workers, and environmentalists to resist this process of agricultural restructuring.

\section{References}

Chrisman, S. (2016). Under contract: Farmers and the fine Print: Viewers guide. Pittsboro, North Carolina: Rural Advancement Foundation International (RAFI-USA). Retrieved from http://rafiusa.org/undercontractfilm/wpcontent/uploads/2017/01/Under_Contract_Viewers-Guide_2017_ReducedFileSize.pdf

Daniel, P. (2013). Dispossession: Discrimination against African American farmers in the age of civil rights. Chapel Hill: The University of North Carolina Press.

Gray, L. (2014). We just keep running the line: Black southern women and the poultry processing industry. Baton Rouge: Louisana State University Press. http://1supress.org/books/detail/we-just-keep-running-the-line/

National Chicken Council. (2017). Per capita consumption of poultry and livestock, 1965 to estimated 2018, in pounds [Table based on USDA data]. Retrieved March 2018 from http://www.nationalchickencouncil.org/about-theindustry/statistics/per-capita-consumption-of-poultry-and-livestock-1965-to-estimated-2012-in-pounds/

Pew Environment Group. (2011). Big chicken: Pollution and industrial poultry production in America. Washington, D.C.: Author. Retrieved from http://www.pewtrusts.org/ /media/legacy/uploadedfiles/peg/publications/report/pegbigchickenjuly2011pdf.pdf

Ribas, V. (2015). On the line: Slaughterhouse lives and the making of the New South. Oakland: University of California Press. https://www.ucpress.edu/ebook.php?isbn=9780520958821

Rural Advancement Foundation International [RAF]. (n.d.). Understanding contract agriculture. Retrieved on January 30 , 2018, from http://rafiusa.org/programs/contract-agriculture-reform/understanding-contract-agriculture/

Simon, B. (2017). The Hamlet Fire : A tragic story of cheap food, cheap government, and cheap lives. New York: The New Press. https://thenewpress.com/books/hamlet-fire

Striffler, S. (2005). Chicken: The dangerous transformation of America's favorite food. New Haven, Connecticut: Yale University Press. https://yalebooks.yale.edu/book/9780300095296/chicken

Stuesse, A. (2016). Scratching out a living: Latinos, race, and work in the Deep South. Oakland: University of California Press. https://www.ucpress.edu/ebook.php?isbn=9780520962392 